\title{
タンゴール“清見”果実のこはん症発生と生理・ 化学的変化に及ぼすポリエチレン包装の効果
}

\author{
阿部一博*・鄧紅* ・矢野昌充 ${ }^{* * *}$ \\ 長谷川美典**・岩 田 隆*
}

Effects of Polyethylene Packaging on the Occurrence of Rind-oil Spot and the Physiological and Chemical Changes in Tangor 'Kiyomi' Fruits

\author{
Kazuhiro Abe*,Hong Beng*,Masamichi Yano**,Yoshinori Hasegawa* and Takashi Iwata* \\ * College of Agriculture, University of Osaka Prefecture, Gakuen-cho, Sakai, Osaka 593 Japan \\ ** Okitsu Branch, Fruit Tree Research Station, Okitsu-nakamachi, Shimizu, Shizuoka 424-02 Japan
}

Tangor 'Kiyomi'(Citrus sinensis $\times$ C. tangerina) fruits were stored at $5^{\circ} \mathrm{C}$ for 2 or 3 months and transferred to $8^{\circ} \mathrm{C}$ or $20^{\circ} \mathrm{C}$. Effect of polyethylene(PE) packaging after tranferring on the occurrence of rind-oil spot injury and the physiological and chemical changes were determined.

The fruits transferred to $20^{\circ} \mathrm{C}$ showed more severe injury than those to $8^{\circ} \mathrm{C}$ after transferring, and sealing in PE bag reduced the injury in both fruits held at $8^{\circ} \mathrm{C}$ and $20 t^{\circ} \mathrm{C}$. The difference in thickness $(20 \mu \mathrm{m}$ or $50 \mu \mathrm{m})$ of PE film showed little effect. In organoleptic evaluation, the appearance of sound fruit was superior to injured fruit, but the taste of both fruits did not differ.

The concentrations of carbon dioxide and ethylene in central cavities of injured fruit were higher than those of sound fruits, and that of oxygen in injured fruit was lower. The respiration rate of injured fruit was higher than sound fruit.

The free amino acid content in peel of fruit increased as the injury developed after tranferring, and phenols accumulated in injured fruit peel. Contents of alcohol insoluble substances in injured fruit was higher than that of sound one.

(Received May 29, 1992)

\section{緒言}

タンゴール“清見”（C. sinensis $\times$ C. tangerina）は 耐寒性と耐病性を有し, その果実は食味が良く特有の 芳香があるため生食のみならず加工用の面でも優れた 品種とされ1), 近年生産量が伸びている。しかし, “清 見” 果実は低温貯蔵中和よび出庫後に果皮にこはん症 (虎斑症：以下こはん症)が発生しやすく, そのため商
品価値が著しく低下寸るので, 流通時の重要な問題と なっている。“清見”のこはん症発生は従来こはん症が 問題とされてきたハッサクなどの品種より出やすいと いわれている2)

カンキッ類のこはん症の発生原因として, 古くから 栽培上の虫害(5)や傷害 ${ }^{4), 6)}$, 収穫後貯蔵中の低温 ${ }^{7) ~ 9) ~}$ 低湿(6),10),11)，物理的損傷に伴い渗出した揮発性物質の

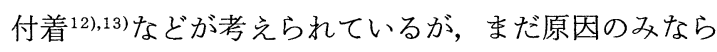


ず，発生条件さえ十分には明らかにされていない。と くに障害発生の原因を生理・化学的な面から調べた報 告は少ない。

本研究は，低温貯蔵した“清見” 果実の出庫後のこ はん症発生に及洔すポリェチレンフィルム包装の抑制 効果, 包装内の環境拉よび果実内ガス, 果実の化学成 分変化などを調べ，こはん症発生要因の一端を明らか にしょうとしたものである。

\section{材料および方法}

供試 “清見” 果実は農林水産省果樹試験場興津支場

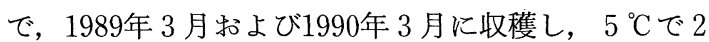
か月あるいは 3 か月間貯蔵したものを，適宜，無包装 のま李，もしくは低密度ポリエチレン袋 $(180 \mathrm{~mm} \times 130$ $\mathrm{mm}$, 厚さ $20 \mu \mathrm{m}$ あるいは $50 \mu \mathrm{m})$ で個装し, 以後 $8{ }^{\circ} \mathrm{C}$ あるいは $20^{\circ} \mathrm{C} て ゙ 30$ 日間保持した。ポリエチレン包装は 密封包装か有孔包装（直径 $5 \mathrm{~mm}$ の孔24個）とした。

各保持区あたり12個の果実でこはん症の発生率なら びに症状程度を 5 段階(無, 軽：黄色 pitting が $1 \sim 2$ 個, 中 : pitting $か ゙ 3 \sim 4$ 個, 甚: pitting 褐変：果実全体に pitting と褐変) で観察し, 重量の 減少も経時的に調查した。各保持区とも観察用とは異 なる 6 ～個の果実を調査日ごとに化学成分などの分 析に供した。果実の呼吸量と果実空隙中ならびに袋内 のガスはガスクロマトグラフィーで測定した。果実空 吵中のガスは袋外より果実の果心部に注射針を挿入し て, $1 \mathrm{ml}$ を採取し分析した。果皮の総遊離アミノ酸 含量は $80 \%$ 熱アルコール抽出液を用いて，ニンヒドリ ン法で比色定量し, カンキッ果汁タンパク質の主要ア ミノ酸のひとつであるグルタミン酸に換算した。果皮 のフェノール物質含量も $80 \%$ 熱ェタノール抽出液につ いて Arnow の方法によって測定し，クロロゲン酸に 換算した。アルュール不溶性物質（AＩＳ）含量は真 空乾繰したアルコール不溶性固形物の重量を測定し， 新鮮物に対する割合を\%で表した ${ }^{14)}$ 。

\section{実 験 結 果}

\section{1.“清見”果実のこはん症発生状況}

果実出庫後のこはん症発生率揖よび症状の程度は Fig.1 (1989年) に示した。各区はそれぞれ保持 5，10， 15，20，25，30日にこはん症の発生程度を 5 段階に分 けて調査を行った。

実験 I（ $5{ }^{\circ} \mathrm{C}$ 貯蔵 2 か月後出庫）のこはん症の発生 は $20^{\circ} \mathrm{C}$ 保持区では早く, 高率であり, $8{ }^{\circ} \mathrm{C}$ 保持区では
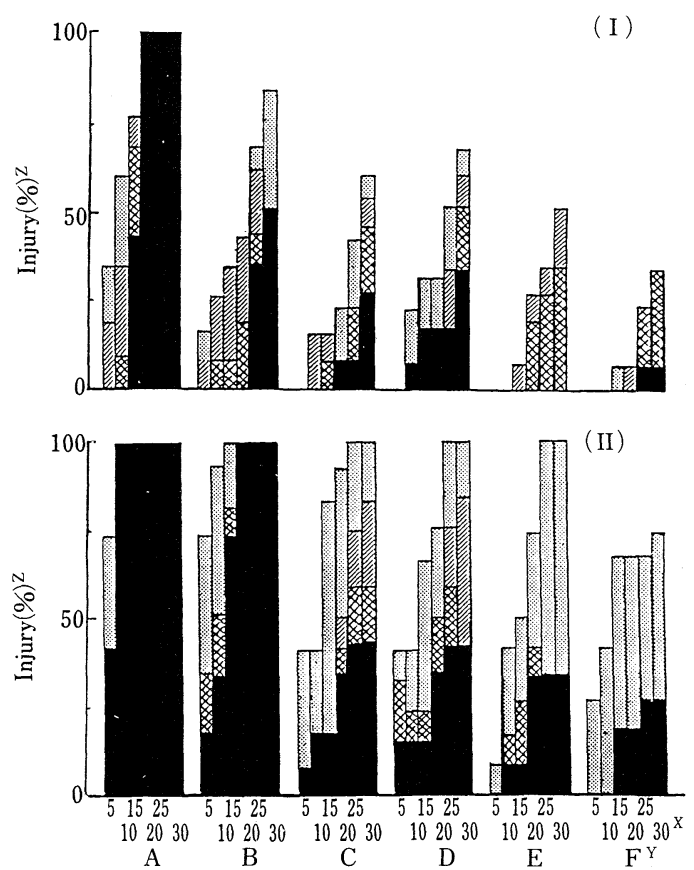

Fig. 1 Incidence of rind-oil spot on 'Kiyomi' fruits stored at $5^{\circ} \mathrm{C}$ for $2(\mathrm{I})$ or $3(\mathrm{II})$ months then transferred to $20^{\circ} \mathrm{C}$ or $8^{\circ} \mathrm{C}$

z; Degree of injury- : : slight,

: severe, $\mathbf{a}$ : most severe

; A : $20^{\circ} \mathrm{C}$, no packaging, $\mathrm{B}: 20^{\circ} \mathrm{C}$, perforated $\mathrm{PE}$ bag, $\mathrm{C}: 20^{\circ} \mathrm{C}$, sealed PE bag $(20 \mu \mathrm{m}), \mathrm{D}: 20^{\circ} \mathrm{C}$, sealed PE bag $(50 \mu \mathrm{m}), \mathrm{E}: 8^{\circ} \mathrm{C}$, perforated PE bag, $\mathrm{F}: 8^{\circ} \mathrm{C}$, sealed $\mathrm{PE}$ bag $(20 \mu \mathrm{m})$

x; Days after transferring

遅く，低率であった。また $20^{\circ} \mathrm{C}$ 保持区においては，無 包装区が最も顕著で, 有孔区では明らかに軽減され, 密封区では一層顕著に発生が抑制された。フィルムの 厚さによる発生程度の違いには一定の傾向がみられな かった。 $8{ }^{\circ} \mathrm{C}$ に打いても密封区では有孔区より障害の 発生が軽減された。

実験 II（ $5{ }^{\circ} \mathrm{C}$ 貯蔵 3 か月後出庫）のこはん症の発生 は実験 Iより多かったが，ポリェチレン包装による障 害発生軽減効果や, $20^{\circ} \mathrm{C}$ での発生が $8{ }^{\circ} \mathrm{C}$ の場合より多 いことは実験 I と同様であった。

1990年收穫果実のこはん症発生は1989年の果実より 少なかったが，出庫後のポリエチレン包装による障害 発生の軽減効果は前年同様明らかであった（図表の表 示は省略)。

2. 包装内および果実内のガス組成と呼吸量の变化 1)包装内ガス組成の変化冷蔵出庫後の包装内の 


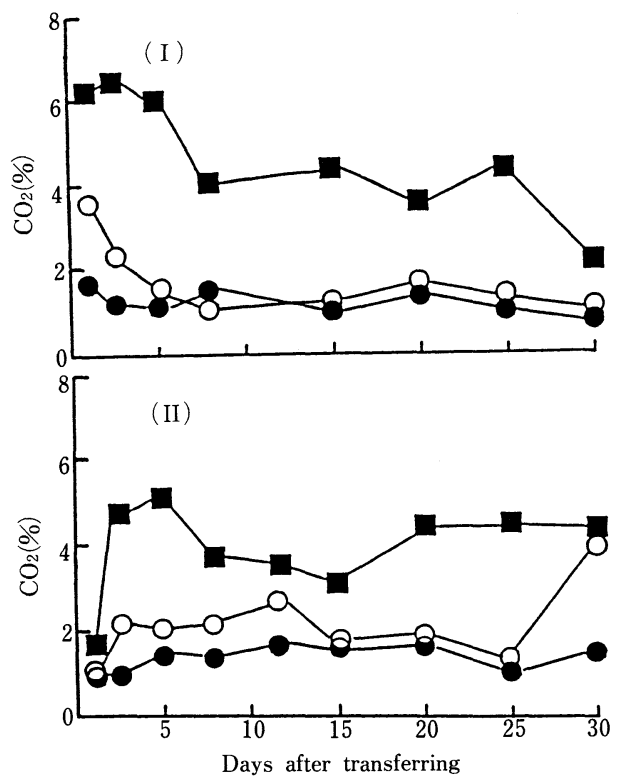

Fig. 2 Changes of $\mathrm{CO}_{2}$ concentrations in polyethylene bag (PE) containing 'Kiyomi' fruits transferred to $20^{\circ} \mathrm{C}$ or $8^{\circ} \mathrm{C}$ from $5^{\circ} \mathrm{C}$ storage for $2(\mathrm{I})$ or 3 (II) months

口 : $20^{\circ} \mathrm{C}$, sealed in PE bag $(50 \mu \mathrm{m})$

$\mathrm{O}: 20^{\circ} \mathrm{C}$, sealed in PE bag $(20 \mu \mathrm{m})$

: $8^{\circ} \mathrm{C}$, sealed in PE bag $(20 \mu \mathrm{m})$

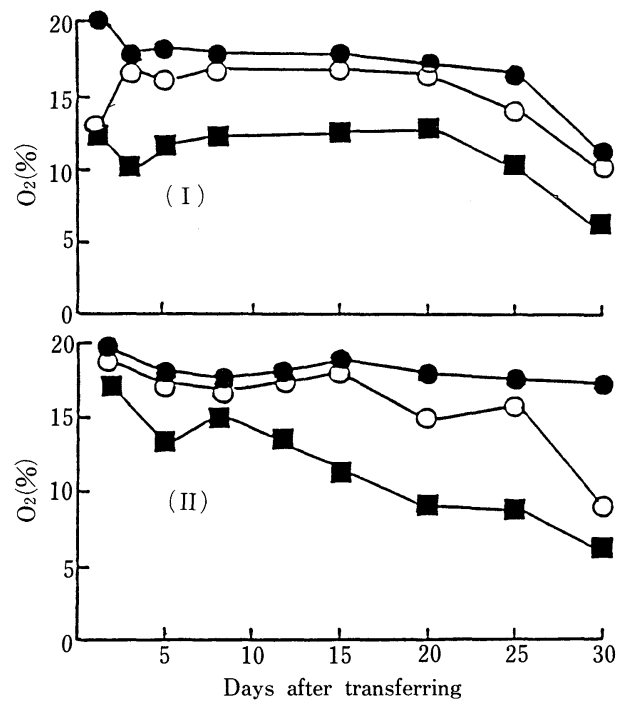

Fig. 3 Changes of $\mathrm{O}_{2}$ concentrations in polyethylene bag containing 'Kiyomi' fruits transferred to $20^{\circ} \mathrm{C}$ or 8 ${ }^{\circ} \mathrm{C}$ from $5{ }^{\circ} \mathrm{C}$ storage for $2(\mathrm{I})$ or $3(\mathrm{II})$ months

a, $\bigcirc$, and $\bigcirc$ : same as in Fig. 2
$\mathrm{C} \mathrm{O}_{2}$ 濃度の変化を Fig. 2 に示した。実験 I $\left(5{ }^{\circ} \mathrm{C}\right.$ 貯 蔵 2 か月後出庫）では $20^{\circ} \mathrm{C} に$ 保持したフィルム厚50 $\mu \mathrm{m}$ の密封区では出庫直後 $6 \%$ 程度であったが，その 後 $4 \%$ 前後に減少した。フィルム厚 $20 \mu \mathrm{m}$ の $20^{\circ} \mathrm{C}$ 密封 区扣よび $8{ }^{\circ} \mathrm{C}$ 密封区も出庫当初はそれぞれ $4 \%$ 和よび $2 \%$ あっただいずれも保持中に約 $1 \%$ に減少した。 実験 II $\left(5{ }^{\circ} \mathrm{C}\right.$ 貯蔵 3 か月後出庫) でも $20^{\circ} \mathrm{C}$ 保持の $50 \mu \mathrm{m}$ 密封区は約 $4 \%, 20^{\circ} \mathrm{C}$ 扔よび $8{ }^{\circ} \mathrm{C} 20 \mu \mathrm{m}$ 密封区は約 2 \%に落ち着いた。

包装内の $\mathrm{O}_{2}$ 濃度 (Fig. 3 ) の変化は実験 I において は, $20^{\circ} \mathrm{C}$ 保持の $50 \mu \mathrm{m}$ 密封区では保持当初から 20 日ま では約 $13 \%$ の濃度を保ち，その後減少し30日には約 6 \%になった。 $20^{\circ} \mathrm{C}$ の $20 \mu \mathrm{m}$ 密封区と $8{ }^{\circ} \mathrm{C}$ 密封区も保持 20日まではそれぞれ $16 \%$ と 17\%程度でほぽ一定であっ たが，以後両区とも減少し 30 日には約11\%となった。

一方実験 II では $20^{\circ} \mathrm{C}$ 保持の $20 \mu \mathrm{m}$ 密封区は実験 I とほ ぼ同様に変化したが， $50 \mu \mathrm{m}$ 密封区は保持当初の17\% から保持 30 日の $6 \%$ まで添淔線的な減少を示した。 $8{ }^{\circ} \mathrm{C}$ 密封区は保持 30 日まで約 $18 \%$ でほぼ一定であっ た。

実験 I の袋内エチレン濃度の変化は(Fig. 4), $20^{\circ} \mathrm{C}$ 保持の $50 \mu \mathrm{m}$ 密封区は 5 日に約 $1 \mathrm{ppm}$ まで急増し, 一 時 $0.6 \mathrm{ppm}$ に減少したものの 25 日に再び $1 \mathrm{ppm}$ 近く に増加した後に急激した。 $20^{\circ} \mathrm{C}$ 保持の $20 \mu \mathrm{m}$ 密封区と

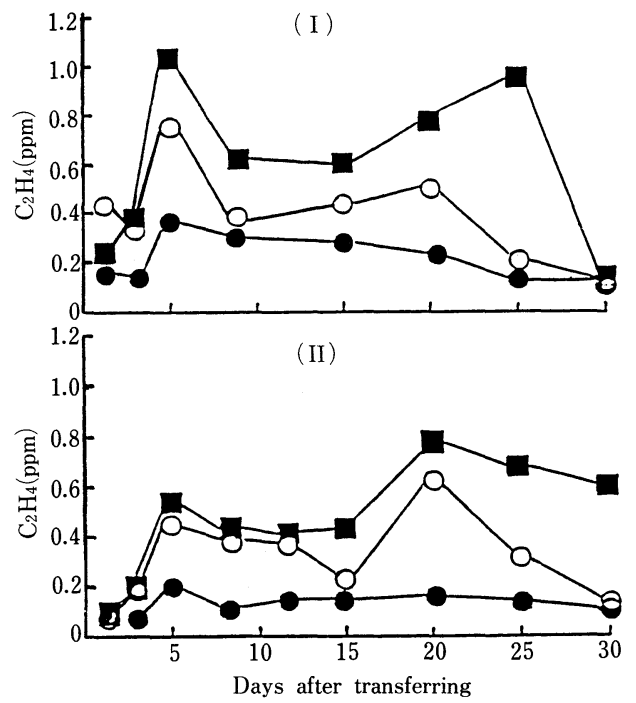

Fig. 4 Changes of $\mathrm{C}_{2} \mathrm{H}_{4}$ concentrations in polyethylene bag containing 'Kiyomi' fruits transferred to $20^{\circ} \mathrm{C}$ or $8^{\circ} \mathrm{C}$ from $5^{\circ} \mathrm{C}$ storage for $2(\mathrm{I})$ or 3 (II) months

$\mathbf{\square} \bigcirc$, and $\bigcirc$ : same as in Fig. 2 
$8{ }^{\circ} \mathrm{C}$ 密封区も同様のパターンを示したが, 前者で 0.4 $\mathrm{ppm}$ ，後者で $0.3 \mathrm{ppm}$ 前後が主であった。実験IIでは $20^{\circ} \mathrm{C}$ 保持の $50 \mu \mathrm{m}$ 密封区は 5 日に増加した後 15 日をで 約 $0.4 \mathrm{ppm}$ を保ち, 20 日以降は0.6〜0.8ppm となった。 $20^{\circ} \mathrm{C}$ の $20 \mu \mathrm{m}$ 密封区は約 $0.4 \mathrm{ppm}, 8{ }^{\circ} \mathrm{C}$ 密封区は 0.15 ppm 程度が主であった。

一般にカンキッ類は土チレン生成が非常に少ない $(0.1 \mu \mathrm{l} / \mathrm{kg} \cdot \mathrm{hr}$ 以下)が，上記のように冷蔵された“清 見” 果実を出庫すると, $20^{\circ} \mathrm{C}$ 保持ではポリェチレン包 装内の濃度は常に $0.2 \mathrm{ppm}$ 以上を示し, $8{ }^{\circ} \mathrm{C}$ 保持に特 いても $0.1 \mathrm{ppm}$ 以上の濃度を示した。

2）果実内ガス濃度の変化 保持期間中の果実をこ はん症発生果実 (障害果) と外観的に障害のみられな い果実（健全果）に分けて，果実空陌中のガスの変化 を調べたところ(Fig. 5), 出庫時に約 $10 \%$ であった果 実内 $\mathrm{O}_{2}$ 濃度は出庫後減少し, 減少は包装の有無にかか わらず，健全果より障害果で顕著であった。
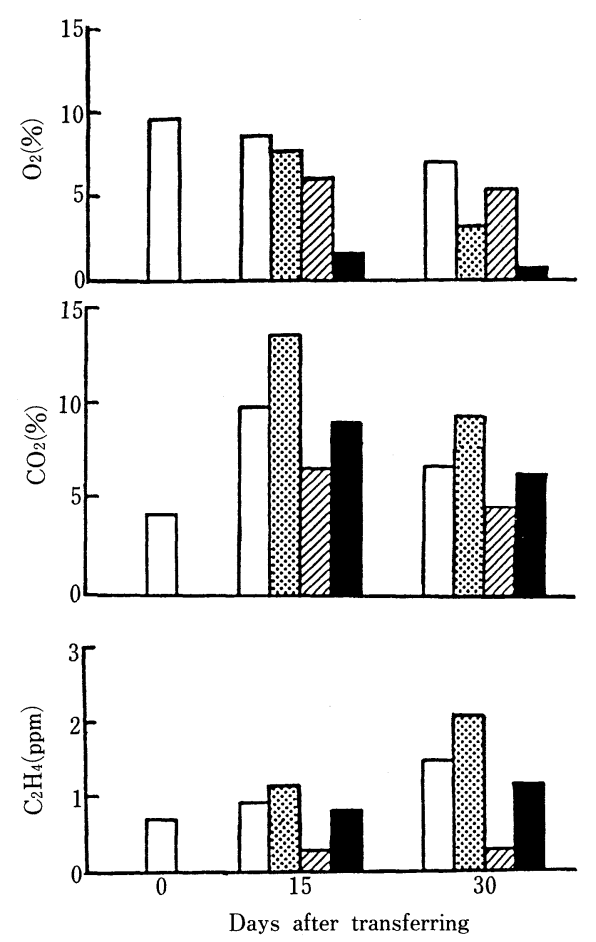

Fig. 5 Changes of $\mathrm{O}_{2}, \mathrm{CO}_{2}$, and $\mathrm{C}_{2} \mathrm{H}_{4}$ concentrations in central cavities of injured or sound 'Kiyomi' fruits stored at $5^{\circ} \mathrm{C}$ for 2 months then transferred to $20^{\circ} \mathrm{C}$.

$\square$ : sound fruits, no packaging

: injured fruits, no packaging

组: sound fruits, sealed in PE bag $(50 \mu \mathrm{m})$

$\mathbf{\square}$ : injured fruits, sealed in PE bag $(50 \mu \mathrm{m})$
果実空隙中の $\mathrm{C} \mathrm{O}_{2}$ 濃度は出庫時は約 $4 \%$ であった。 出庫後15日ならびに 30 日ともに濃度は包装の有無にか かわらず障害果の方が健全果より高く，保持15日では 無包装の障害果は約 $14 \%$ に達した。

$\mathrm{C}_{2} \mathrm{H}_{4}$ 濃度は出庫後増加する傾向がみられ, $\mathrm{C} \mathrm{O}_{2}$ 濃 度同様に障害果の方が健全果より高く, 保持 30 日の障 害果では約1.5ppm (包装) 〜 2 ppm (無包装)を示し た。

3) 出庫後の果実呼吸量の変化 出庫後 $20^{\circ} \mathrm{C}$ 保持 期間中に打ける健全果と障害果の呼吸量の変化を Fig. 6 に示した。保持15日には障害が発生しやすい無 包装区では $\mathrm{C} \mathrm{O}_{2}$ 排出量が密封区より高く，また障害果 は健全果の約 2.0 倍であった。密封区に招いても障害果 の $\mathrm{C} \mathrm{O}_{2}$ 排出量は健全果の1.4倍であった。保持30日に おいては密封区では15日と同様であったが，無包装区 では障害果の $\mathrm{C} \mathrm{O}_{2}$ 排出量が低下し，健全果と障害果の 呼吸量の差はみられなかった。

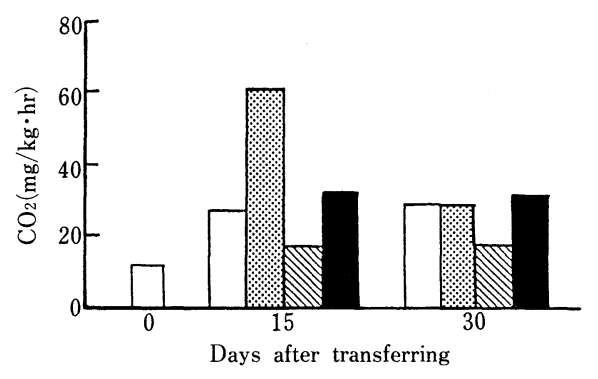

Fig. 6 Changes of carbon dioxide productions of injured and sound 'Kiyomi' fruits stored at $5{ }^{\circ} \mathrm{C}$ for 2 months then transferred to $20^{\circ} \mathrm{C}$

$\square$, $: \mathbb{N}, \square$ : same as in Fig. 5

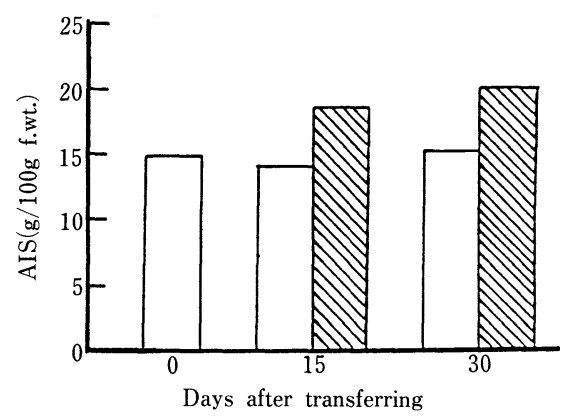

Fig. 7 Changes of alcohol insoluble substances (AIS) content in peels of injured and sound 'Kiyomi' fruits Fruits were stored at $5^{\circ} \mathrm{C}$ for 2 months then transferred to $20^{\circ} \mathrm{C}$.

$\square$ : sound fruits, sealed in PE bag $(50 \mu \mathrm{m})$

$\mathbb{N}$ : injured fruits, sealed in PE bag $(50 \mu \mathrm{m})$ 

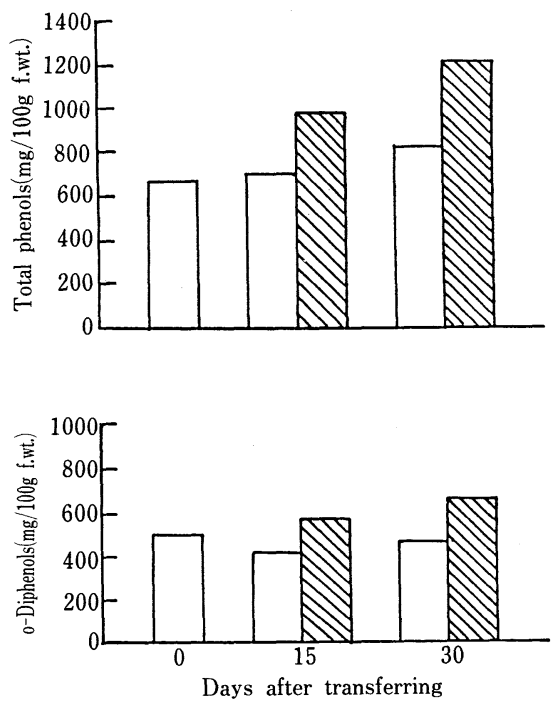

Fig. 8 Changes of phenols contents in peels of injured and sound 'Kiyomi' fruits

Fruits were stored at $5{ }^{\circ} \mathrm{C}$ for 2 months then transferred to $20^{\circ} \mathrm{C}$.

$\square$ : same as in Fig. 7

3. “清見”果実のこはん症発生に伴う果皮成分の 変化

1）果皮のアルコール不溶性物質の変化 健全果 の果皮のアルコール不溶性物質は保持期間中あまり変 化しなかったが，障害果では増加した（Fig. 7)。

2）果皮褐変に伴うフェノール物質含量の変化 果皮のオルトジフェノール含量が総フェノール物質の 中に占める割合は出庫時で約70\%であった。保持15日 と30日では障害果の総フェノール物質ならびにオルト ジフェノール含量は明らかに増大したが健全果ではあ まり変わらなかった（Fig. 8)。

3）果皮の遊離アミノ酸の変化 実験 I ならびに 実験 II とも果皮中の遊離アミノ酸含量は保持期間中増 加する傾向がみられたが, 増加の程度は各保持区のこ はん症の発生程度と平行する関係がみられ，こはん症 の発生が多い $20^{\circ} \mathrm{C}$ 無包区では遊離アミノ酸含量の増加 が最も多く，障害発生がある程度抑えられた密封区で は低く，障害の少ない $8{ }^{\circ} \mathrm{C}$ の有孔区打よび密封区では 増加が最も少なかった（Fig. 9)。

4. “清見”果実出庫後の果汁成分と食味の変化

果実出庫後に打いて果汁の糖度, 滴定酸含量, 果汁 $\mathrm{pH}$ とも顕著な変化はみられなかった（図表の表示は 省略)。

出庫後 $15 ， 25 ， 30$ 日に果実の品質を外観，香り，甘
味，酸味，苦味，総合評価の項目について 5 段階評価 法で宫能検查を行ったところ, 香り, 甘味, 酸味, 苦 味の調査項目に打いては各保持区の間には顕著な差は みられなかった。しかし，こはん症の発生がみられた 区では外観の評点が低く，特に無包装区は果皮の萎调 打よびこはん症の発生のため外観が悪く，総合評価は 低かった（図表の表示は省略）。

\section{考察}

“清見”果実も他のカンキッ類と同様に，こはん症 の発生は低温貯蔵期間が長いほど多く発生し，末た出 庫後の保持温度が高い $\left(20^{\circ} \mathrm{C}\right)$ 方が低い場合 $\left(8{ }^{\circ} \mathrm{C}\right)$ よりこはん症の発生が多かった。しかし,1989年と1990 年の両年の供試材料は, 同一圃場で慣行法で栽培され, 同時期に収穫後，同一条件下で冷蔵や $20^{\circ} \mathrm{C}$ へ出庫が 行われたにもかかわらず発生程度に明らかな差異がみ られた。これは栽培中の要因も“清見”のこはん症の 発生に影響を及ぼすと考兄られる。泉占)も同じ産地の ハッサクを用い，収穫年度によってこはん症の発生率 が相違していることを観察している。栽培期間中の要 因は個々が複雑に関連しているので，その関連を明ら かにするのは容易でないと思われる。

カンキッ類を低温貯蔵後に昇温すると呼吸量が急激
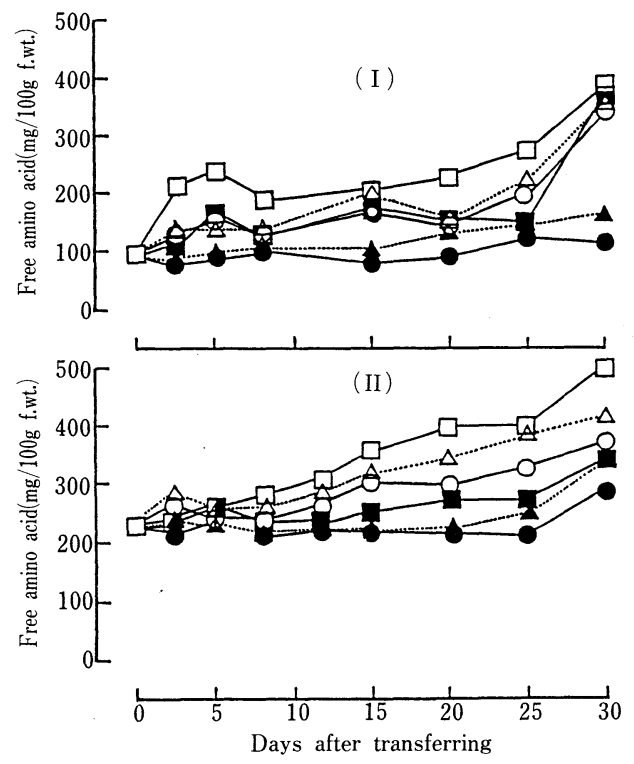

Fig. 9 Changes of free amino acid contents in peel of ' $\mathrm{Ki}$ yomi' fruits transferred to $20^{\circ} \mathrm{C}$ or $8^{\circ} \mathrm{C}$ from $5^{\circ} \mathrm{C}$ storage for 2 (I) or 3 (II) months $\mathrm{A}-\square, \mathrm{B}-\triangle, \mathrm{C}-\mathrm{O}, \mathrm{D}-\mathbf{\mathbf { Q }}, \mathrm{E}-\mathbf{\Delta}, \mathrm{F}-\mathbf{0}$ : same as in Fig. 1 
に増加する現象と低温障害の関連性について報 告7),16),17)されているが，“清見”に扔いても出庫後果実 の呼吸量が増加しその増加は障害果の方が健全果より 顕著で，障害果空隙中のエチレン含量も健全果より高 いことから，果実の生理代謝に異常が生じていること が明らかである。

また，ポリエチレン包装は腐敗果が多くなるものの 出庫後のこはん症発生を軽減する効果が明らかであっ た。これには岩田らがウメ果実の低温障害がポリエチ

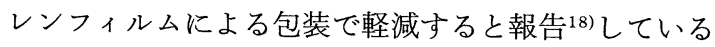
のと同様に, 包装内の酸素濃度の低下と二酸化炭素濃 度の増加が関連すると思われる。一方, 昇温後の温度 にかかわらず，こはん症は無包装区>有孔区>密封区 の順で発生が多くなったことより，ポリェチレン包装 によるこはん症抑制効果は果実周辺の湿度を高くする こともある程度は寄与すると思われた。ただし, 密封 包装の場合は包装内の湿度は $100 \%$ 近くに達している にもかかわらず, こはん症の発生がみられたことから, 低湿度条件が決定的なものではない。A I S は健全果 より障害果で多かったが，これも障害が発生すること によって水分損失が生じた結果と思われる。な执，障 害発生の多い無包装区や有孔区の水分損失は $5 \sim 8 \%$ であり, 障害の少ない密封包装区は $1 \%$ 以下であった。

青果物の酵素的褐変には, フェノール物質の酸化が 関与することは知られて和り, 筆者らはフェノール物 質の蓄積はナス果実の低温障害発生の一因と報告して (る19) 22)。“清見”果実もこはん症が進むと褐変し, 障 害果は健全果よりフェノール物質の含量が多かったこ とから, “清見”果実のこはん症にもフェノール物質の 蓄積が何らかの役割を果たしていると思われた。

総遊離アミノ酸が緑黄野菜の黄化に伴い増加し, そ れはプロテアーゼによるタンパク質の分解によるるの で, 総遊離アミノ配含量の变化が緑黄野菜の品質指標 とされることが多(23) 25)。貯蔵果実の品質低下に伴う 総遊離アミノ酸含量の報告は葟とんどみられないが本 研究では“清見” 果皮に拈いて，こはん症の発生しや すい保持区は発生しにくい保持区より総遊離アミノ酸 の増加が明らかであったことから, “清見”果皮に打け る総遊離アミノ酸含量の変化は品質低下の指標となる ものと考光られる。

\section{摘 要}

$5{ }^{\circ} \mathrm{C} て ゙ 2$ かもしくは 3 か月間貯蔵した“清見” 果 実を個別にポリエチレン袋で密封あるいは有孔包装し $20^{\circ} \mathrm{C}$ おび $8{ }^{\circ} \mathrm{C}$ に保持してこはん症の発生と生理・化 学的変化を調べた。対照は無包装とした。

$20^{\circ} \mathrm{C}$ 保持では $8{ }^{\circ} \mathrm{C}$ に比べこはん症の発生が顕著であ った。ポリェチレン袋個装によって無包装に比べこは 儿症の発生が明らかに軽減された。密封区は有孔区に 比べ効果が大きかった。フィルムの厚さ $(20 \mu \mathrm{m}, 50$ $\mu \mathrm{m} ） に よ る$ 違いには一定の傾向がみられなかった。

こはん症の発生率が高い $20^{\circ} \mathrm{C}$ 無包装区は包装区より 果実空隙中の $\mathrm{CO}_{2}$ ならびにェチレン濃度は高い傾向 がみられ, 酸素濃度も保持30日の無包装区の障害発生 果以外では無包装区が包装区より高かった。障害果で は健全果より, 果実空吵中の $\mathrm{CO}_{2}$, エチンン濃度が高 $く, \mathrm{O}_{2}$ 濃度が低い傾向がみられた。障害果の $\mathrm{CO}_{2}$ 排出 量は健全果より高かった。

果皮中の遊離アミノ酸含量は, 障害発生に伴い増加 する傾向があり, 増加の程度はこはん症発生程度の高 い果実で大きかった。こはん症の発生した果実の果皮 にはフェノール類物質の蓄積が観察された。

官能検査では, こはん症が発生した果実の外観の評 点は明らかに低かったが, 果肉品質の評点は大きく変 化しなかった。

\section{参考文献}

1）西蒲昌男 ・ 七條寅之助 ・上野 勇・岩政正男・木原武士 ・山 田杉雄・吉田俊雄 - 岩崎藤助: 果樹試報 B, 10, 1 (1983)

2）佐藤瑞穂・佐藤 隆・ 三股 正・秋田忠夫：九州農研報， 45 , 251 (1983)

3）田中秀幸：農耕と園芸，208（1990）

4）長谷川美典 - 矢野昌充：園学雑, 59 (別 1)，620（1990）

5）牛山隆司 - 内田正人：神奈川園試研報, 15, 19 (1967)

6）小川勝利·坂井 堅·黑川泰幸：広島果試研報， 5,17 (1979)

7）岩田 隆・中川勝也・緒方邦安：園学雑，37,383（1968）

8）山下重良：園学䧴誌，36，110（1967）

9) Eaks, I. L. : Proc. Amer. Soc. Hort. Sci., 66, 141 (1960)

10）近泉惣次郎・天野勝司・秋好広明・渡部潤一郎・松本和夫： 園芸学会要旨集, 昭60秋，428（1985）

11）船上和書・西山富久・石田善一：園芸学会要旨集, 昭61秋, 440 (1986)

12）真子正史：園芸学会要旨集, 昭59春, 393 (1984)

13）真鍋 糺・安岡 研: 園芸学会要旨集, 昭 57 秋, 92 (1982)

14）大阪府立大学農学部園芸学教室編：園芸学英験・実習（養賢

堂, 東京), (1983)

15）泉 秀実·伊東卓爾・吉田保治：園学雜 59 (別 2 ), 698(1990)

16) Eaks,I. L. : Plant Physiol.,35, 632 (1955)

17）吉松敬祐・内山善雄: 園芸学会要旨集, 昭55秋, 388 (1980)

18）岩田 隆・木下光子：園学雑, 47, 97 (1978)

19）阿部一博・緒方邦安：園学雑, 47, 111 (1978)

20）阿部一博・茶珍和雄・緒方邦安：園学雑，49，269（1980）

21）阿部一博：茶珍和雄：日食低温誌，15，119（1989） 
22) ABE. K.: Chilling Injury of Horticultural Crops, Ed. Wang. C. Y., C. R. C Press. (1990)

23）農林水産省中国農業試験場編：品質評化法に関する統一調 查法 (1985)

24）阿部一博：園芸利用に関する研究成績報告書（大農技資 426), 1, (1985)
25）阿部一博：園芸利用に関する研究成績報告書（大農技資 439), 2, (1986)

(平成 4 年 5 月 29 日受理) 